\title{
INPUT-OUTPUT ANALYSIS AND INTERRELATIONAL INCOME MULTIPLIER AS A MATRIX
}

\author{
By KENICHI MIYAZAWA*
}

\begin{abstract}
Contents
I. Introduction

II. Reformulation of the Income Multiplier as a Matrix

III. Income Formation and the Input-Output System

IV. Pattern of the Interrelational Income Multiplier between Regions

V. Composition of. Final Demand and the Multi-sector Income Multiplier

VI. Output Determination and Interregional Income Generation
\end{abstract}

\section{Introduction}

As an extension of the input-output analysis, we had introduced previously a new concept which might be called the "interrelational income multiplier" as a matrix. It was designed to analyse the interrelationships among various income-groups in the process of income formation and tells us how much income in one group is generated by the expenditure from one unit of additional income in the other group through the medium of industrial production activity. Although this multi-sector multiplier follows in Leontief's "interindustry matrix multiplier", it is formulated by the inclusion of the income generation process which is omitted in the usual input-output open model and by projecting the multiplier process into the incomedetermination side rather than the output-determination side.

The model containing this income multiplier has the following two theoretical implications:

(1) In the Keynesian multiplier model of income-determination the same amount of autonomous expenditures can not have different effects on the level of national income even if the expenditures have commodity proportions different from each other. The same criticism holds for the extended models incoporating income-distribution-factors as shown in KaleckiKaldor's type, as far as there are no changes in the relative shares of income and the propensities to consume of each income group. But in the real world, even when these conditions hold, autonomous expenditures of the same amount but different commodity compositions have different effects on income generation. In order to clarify this point, it is not sufficient to introduce the income-distribution-factors alone, but we must introduce the same factors for the industrial production structure.

(2) On the other hand, in the Leontief input-output model, the outputs of industries have different values depending the proportions of autonomous expenditures. But as far as

* Professor $(K y \bar{o} j u)$ of Economics. 
the income sector is concerned, the total income has same value and does not depend on the compositions of autonomous expenditure. This conclusion also holds with the case in which household consumption expenditure is treated as an endogenous variable, as far as we retain the assumption that the level of income and its use do not depend on the composition of production. ${ }^{1}$ In order to conclude that the values of income differ depending on the proportions of autonomous demand, it is necessary to introduce not only the endogenous consumption but also the structure of income distribution by the type of income-group, as well as by the type of industrial value-added.

In this paper we shall present a summarized version of these theoretical ideas ${ }^{2}$ and then compare them with the input-output and related empirical data.

\section{Reformulation of the Income Multiplier as a Matrix}

As shown in the following sections, an application of our model is made for the interregional income-distribution side, so we shall formulate the model in a suitable form for this case. However, the model itself holds good for the other cases such as class-distribution or size-distribution of incomes with some slight alterations being made in the definitions of the coefficients. The ommision of the income formation process in input-output analysis is especially not justified in the interregional interindustry case, because the location of production depends on the location of consumption, and the latter can not be determined separately from the calculation of income generated in each region.

Let us divide $k$ regions into $n$ industry sectors, and write the coefficients of the model as follows:

$A=\left[a_{i j}^{r_{j}}\right] \ldots$ the $n k \times n k$ matrix of interregional input coefficients.

$a_{i j}^{r s}=$ the amomnt of $i$ th commodity produced in region $r$ for use of 1 unit of output of the $j$ th industry in region $s(i, j=1,2, \ldots, n ; r, s=1,2, \ldots, k)$.

$V=\left[v_{j}^{r s}\right] \ldots$ the $k \times n k$ matrix of value-added ratios of household sectors in each region.

$v_{j}^{\tau s}=$ the income of a household in region $r$ earned from 1 unit of production of $j$ th industry in region $s(j=1,2, \ldots, n ; r, s=1,2, \ldots, k)$.

$C=\left[c_{2}^{\tau s}\right]$...the $n k \times k$ matrix of coefficients of regional consumption expenditure. $c_{i}^{r s}=$ the consumption expenditure for the $i$ th commodity produced in region $r$ from 1 unit of income earned in $s$ region's household sector $(i=1,2, \ldots, n ; r, s=1$, $2, \ldots, k) .^{3}$

Using the $n k \times n k$ matrix of the usual Leontief interindustrial inverse:

$$
B=[I-A]^{-1}=\left[b_{i j}^{\gamma \delta}\right]
$$

1 This is the case in a closed economy with no foreign trade and government activities. But in the case of an open economy with foreign trade and government activities, the same conclusion does not hold, because the composition of production plays a part in the income formation process through imports, subsidies and taxes.

${ }^{2} \mathrm{~K}$. Miyazawa and S. Masegi, "Interindustry Analysis and the Structure of Income-Distribution" Metroeconomica, Vol. xv, Fas. 2, 3, Agosto-Dicembre, 1963. In this paper, I have introduced some improvements and developments in summarizing the corresponding parts of the above article.

${ }^{8}$ Instead of this definition, if we denote by $e^{s}$ the total propensity to consume in region $s$, and by $h_{i}^{r s}$ the consumption-allocation coefficients for $i$-th commodity produced in region $r$, then we get $e^{s} h_{i}^{r s}=c_{i}^{r s}$. 
the corresponding earnings of income by the household sectors in each region are easily determined as follows:

$$
V B=\left[\sum_{j, s} v_{j}^{r g} b_{j i}^{s r}\right]
$$

which forms the $k \times n k$ matrix of coefficients showing induced income earned from production activities among industries and regions. On the other hand, the induced production due to endogenous consumption per 1 unit of income in each region's household sector is given as the following $n k \times k$ matrix:

$$
B C=\left[\sum_{i, r} b_{j i}^{s r} c_{i}^{r s}\right]
$$

Jointing these two expressions, we get the following matrix:

$$
\begin{aligned}
V B C & =\left[\sum_{j, p} \sum_{i, q} v_{j}^{\tau p} b_{j i}^{p q} c_{i}^{q g}\right] \\
& =\left[l^{r s}\right]=L,
\end{aligned}
$$

square because the multiplication of rectangular and square matrices $V, B$ and $C$ makes a new $k \times k$ square matrix whose order equals to the number of regions. This square matrix $L$ may be interpreted as a set of coefficients which show the interrelationships among incomes of various regions through the process of propagation from consumption expenditure in each region. Its elements $l^{r s}$ show how much income in region $r$ is generated by the expenditure from 1 unit of additional income in the region $s$. Thus we may term $L$ the "matrix of interincome-group coefficients".

Of course, the income propagation process does not stop in the one round inducement indicated by the coefficient matrix $L$ because the next round of earnings will take place due to the production activity induced by the expenditure from the preceding round of additional incomes. This has come to be called the successive income generating process. Ultimately, such successive repercussion process naturally leads to the intersectoral income multiplier among regions of the following type:

$$
K=[I-L]^{-1}=\left[k^{r s}\right] .
$$

The matrix $K$ will be called the "interrelational income multiplier as a matrix" which shows the direct and indirect income-generation per unit of income originated where, of course, $I$ is the identity matrix having the order of $k \times k$.

Justification of the existence of the formula (2.3) may be attempted by tracing the propagation process caused by the initial autonomous injection of $f$, where $f$ is a column vector having $n k$ order of final demand other than endogenous consumption expenditure. Denote by $Y$ a column vector of $k$ order whose elements are incomes of the household sector in $k$ regions, and by $X$ a column vector of $n k$ order whose elements are outputs of $n$ industries in each $k$ region. Using suffix $m$ in parentheses ( ) to denote the numerical order of propagation, we get

$$
\left\{\begin{aligned}
Y_{(1)}=V X_{(1)} & =V B f \\
Y_{(m)}=V X_{(m)} & =V B C Y_{(m-1)} \\
& =L Y_{(m-1)}=L^{m-1} Y_{(1)} . \quad \text { for } m \geqq 2
\end{aligned}\right.
$$

This gives the expansion in powers as:

$$
\begin{aligned}
Y=\sum_{m=1}^{\infty} Y_{(m)} & =Y_{(1)}+L Y_{(1)}+L^{2} Y_{(1)}+L^{8} Y_{(1)}+\ldots \\
& =\left[I+L+L^{2}+L^{3}+\ldots\right] Y_{(1)} .
\end{aligned}
$$

Hence, if the term $\Sigma L^{m}$ is a convergence, ${ }^{4}$ then we obtain the fundamental equation of income ${ }^{4}$ The convergence conditions of the term $\sum L^{m}$ and the existence of the inverse $K=[I-L]^{-1}$ are generally verified. See' op. 'cit., pp. 97-103. 
formation as followings:

$$
\begin{aligned}
Y & =[I-L]^{-1} V B f \\
& =K V B f .
\end{aligned}
$$

We may designate the $k \times n k$ matrix $K V B$ as the "multi-sector income multiplier as a matrix" or "matrix multiplier of income formation" which takes the following form: the "interrelational income multiplier" $K$ post-multiplied by the coefficient matrix of induced income $V B$. Thus, equation (2.5) will give us the direct and indirect induced incomes in each region due to the initial autonomous demand.

This fundamental equation of income formation (2.5) corresponds to the Keynesian macromultiplier equation, and includes it as a special case. If we do not distinguish between the distribution of incomes between groups or regions, namely, if we put $k=1$, the matrix $V$ becomes the row vector of $n$ order, and correspondingly, the matrix $C$ becomes the column vector of $n$ order. If we write them $v^{\prime}$ and $c$ respectively and assume that the all value-added in the national economy consists of the income of the household sector, ${ }^{5}$ then

$$
\begin{aligned}
L=V B C & =v^{\prime} B c=i^{\prime}[I-A] B c=i^{\prime} c \\
& =\bar{c}(=\text { Keynesian macro-propensity to consume) } \\
K & =[I-L]^{-1}=\frac{1}{1-\bar{c}}
\end{aligned}
$$

where $i^{\prime}$ is a row vector whose elements all equal to 1 . So, the income multiplier equation (2.5) becomes

$$
\begin{aligned}
Y & =K V B f \\
& =\frac{1}{1-\bar{c}} v^{\prime} B f=\frac{1}{1-\bar{c}} i^{\prime} f=\frac{1}{1-\bar{c}} f_{0},
\end{aligned}
$$

where $f_{0}$ is a scalar that means $f_{0}=f_{1}+f_{2}+f_{3}+\ldots+f_{n}$, and then the vector $Y$ becomes a scalar, too. This scalar multiplier coincides exactly with the Keynesian multiplier. Thus our conclusion that income has different values depending on the proportions of exogenous demand, which is verified by the fundamental equation (2.5), disappers in the Keynesian equation.

Further, even if we introduce the income-distribution-factors in macrocosmic from as shown by Kalecki's or Kaldor's models, the above Keynesian result is not improved. Denoting by $d$ the column vector of $k$ order whose elements are relative shares of each incomegroup, ${ }^{6}$ we may rewrite the matrix $V$ as $V=d v^{\prime}$, and the matrix $L$ takes the following form:

$$
L=V B C=d v^{\prime} B C=d i^{\prime} C=d e^{\prime}
$$

where $e^{\prime}=i^{\prime} C$ is the row vector of $k$ order whose elements are the total propensities to consume of each income-group. Then, we get $L^{m}=\left(d e^{\prime}\right)^{m}=d\left(e^{\prime} d\right)^{m-1} e^{\prime}=d l^{m-1} e^{\prime}$, where $l$ is a scalar showing the weighted average of propensities to consume of each income-group. Thus, the interrelational income multiplier in this case is

$$
\begin{aligned}
K & =[I-L]^{-1}=I+\sum_{m=1}^{\infty} L^{m} \\
& =I+\sum_{m=1}^{\infty} l^{m-1} d e^{\prime}=I+\frac{1}{1-l} d e^{\prime},
\end{aligned}
$$

and the fundamental equation may take the form:

\footnotetext{
5 With this assumption, $v^{\prime}$ becomes the vector of value-added ratios for the whole economy, and in an economy with no foreign trade and government activities, the convertion $v^{\prime}=i^{\prime}[I-A]$ becomes possible. Then we get $v^{\prime} B=i^{\prime}[I-A][I-A]^{-1}=i^{\prime} I=i^{\prime}$. Of course, if the household sector accounts for only one part of the value-added sectors in the national economy, this conclusion must be modified.

Where, of course, the sum of all elements of $d$ equals to 1 , i.e., $d^{1}+d^{2}+\ldots+d^{k}=1$.
} 


$$
\begin{aligned}
Y & =K V B f \\
& =\left[I+\frac{1}{1-l} d e^{\prime}\right] d v^{\prime} B f=\left[I+\frac{1}{1-l} d e^{\prime}\right] d i^{\prime} f=\left[d+\frac{l}{1-l} d\right] f_{0} \\
& =\frac{1}{1-l} d f_{0}
\end{aligned}
$$

in which the autonomous demand vector $f$ becomes a scalar $f_{0}$, and the equation (2.9) coincides with the Kalecki multiplier except when it is expressed in some generalized form. In order to convert the above equation into the expression of a scalar multiplier, all that needed is to multiply both sides of equation by $i^{\prime}$, namely,

$$
i^{\prime} Y=i^{\prime} \frac{1}{1-l} d f_{0}=i^{\prime} d \frac{1}{1-l} f_{0}=\frac{1}{1-l} f_{0} .
$$

If we assume the constancy of relative shares, the scalar $l$ always takes a constant value, and, after all, equation (2.10) ends up with the same meaning indicated by the Keynesian multiplier (2.7).

\section{Income Formation and the Input-Output System}

So far, we have limited our argument mainly to the income determination side, but corresponding to this side, the output determination mechanism may play its own role. Therefore, the same fundamental equation of income formation (2.5) must be also derived from this latter aspect of determination.

Denoting by $X$ a column vector of output the same as before, the balancing equation of supply and demand in the input-output system may be stated as follows:

$$
X=A X+f_{c}+f
$$

where $A X$ is the intermediate demand for outputs, and $f_{c}, f$ are respectively vectors of household consumption demand and final demand other than consumption expenditure. By the usual input-output method in which $f_{c}$, as well as $f$, is treated as an exogenous variable, the following well known solution appears:

$$
X=[I-A]^{-1}\left\{f_{c}+f\right\} .
$$

But if we treat the consumption demand $f_{c}$ as an endogenous variable and regard the household sector as a decision-making unit instead of a fictitious production unit, the introduction of the consumption function is necessary.

We shall define the consumption function as

$$
f_{c}=C V X
$$

where the definitions of coefficient matrices $C$ and $V$ is the same as given in section II. If we add the nonhomogenous terms or exogenous elements to the consumption function, $C$ becomes the matrix of marginal coefficients, and in this case we can treat the nonhomogenous terms as included in $f$. Substituting the consumption function (3.3) in (3.1), we get

$$
X=A X+C V X+f
$$

Solving (3.4) for $X$, we obtain the following alternative three expressions:

$$
\begin{aligned}
X & =[I-A-C V]^{-1} f \\
& =B[I-C V B]^{-1} f \\
& =B[I+C K V B] f
\end{aligned}
$$

where of course $B=[I-A]^{-1}$. 
The first expression (i) gives us the "enlarged inverse matrix multiplier" showing the total effects of final demand other than consumption on the outputs through the interindustrial and induced consumption activites, and the existence of the inverse $[I-A-C V]^{-1}$ is generally verified. This expression (i) will be converted into the second expression (ii), namely, the "original Leontief inverse" $B$ postmultiplied by the "subjoined inverse" $[I-C V B]^{-1}$ which shows the effects of endogenous changes in consumption demand of the household sector. This convertion is as follows:

$$
\begin{aligned}
{[I-A-C V]^{-1} } & =\left[\left\{I-C V(I-A)^{-1}\right\}(I-A)\right]^{-1} \\
& =(I-A)^{-1}[I-C V B]^{-1} \\
& =B[I-C V B]^{-1}
\end{aligned}
$$

From an economic view-point, the formula (ii) distinguishes the inverse reflecting consumption activity from the inverse reflecting production activity, in contrast to the formula (i) which does not draw any distinction between these two activities in the matrix multiplier.

The third expression (iii) means that the $n k \times n k$ subjoined inverse $[I-C V B]^{-1}$ can be obtained without inversing the matrix by the means of using the "interrelational income multiplier" $K$ whose order is $k \times k$. Practically speaking, the matrix $K$ is very easily computed since $k$ is very much smaller than $n k .^{7}$ A proof of the identity between (ii) and (iii) is that:

with the definition

$$
\begin{gathered}
K[I-V B C]=I, \\
C K[I-V B C] V B=C V B \\
C K V B[I-C V B]=C V B \\
I-C K V B[I-C V B]=I-C V B \\
I=[I+C K V B][I-C V B] \\
\therefore \quad[I-C V B]^{-1}=I+C K V B
\end{gathered}
$$$$
\text { then }
$$

where identity matrices $I$ 's in the first and second equations have the order of $k \times k$, and those in third and following equations have the order of $n k \times n k$ respectively. This convertion means that the convergency of $\Sigma(C V B)^{m}$ and that of $\Sigma(V B C)^{m}$ or $\sum L^{m}$ are equivalent. ${ }^{8}$ Further, we can prove that the convergence condition of $\Sigma L^{m}$ is also that of $\Sigma(A+C V)^{m}$.

Now, we shall project this output-determination into the income-determination side. As before, denoting by $Y$ the column vector of $k$ order whose elements are household incomes in each region, we get

$$
Y=V X \text {. }
$$

Substituting the formula (iii) of (3.5) into this expression (3.6), the income equation becomes

${ }^{7}$ Since the consumption coefficients and valed-added ratios are not as stable as the input coefficients, equation (iii) gives a practical computation formula by which we can renew the subjoined inverse whenever necessary.

8 Another proof of the identity between (ii) and (iii) by using this equivalency of convergence is that: if the existence of the inverse $[I-C V B]^{-1}$ is warranted, then it means the term $\sum(C V B)^{m}$ is convergence, so we have

in which

$$
B[I-C V B]^{-1}=B\left[I+\sum_{m=1}^{\infty}(C V B)^{m}\right]
$$

Then, we get

$$
\sum_{m=1}^{\infty}(C V B)^{m}=\sum_{m=1}^{\infty} C(V B C)^{m-1} V B=C\left(\sum_{m=0}^{\infty} L^{m}\right) V B=C K V B
$$

$$
B[I-C V B]^{-1}=B[I+C K V B] .
$$




$$
\begin{aligned}
Y & =V B[I+C K V B] f \\
& =[I+V B C K] V B f \\
& =[I+L K] V B f
\end{aligned}
$$

in which $I+L K=K$ because $[I-L] K=I$, so we obtain

$$
Y=K V B f \text {. }
$$

This result coincides perfectly with (2.5) obtained by tracing the propagation in the income generating process itself.

If we lump together the above two mechanisms of output and income determination, we may have the following system:

$$
\left[\begin{array}{l}
X \\
\hline Y
\end{array}\right]=\left[\frac{A \mid C}{V} \mid O\right]\left[\frac{X}{Y}\right]+\left[\frac{f}{g}\right]
$$

Solving this system for $X$ and $Y$, we get

$$
\left[\frac{X}{Y}\right]=\left[\begin{array}{c|c}
I-A & -C \\
\hline-V & I
\end{array}\right]^{-1}\left[\frac{f}{g}\right]
$$

and this solution will be expected to take the form:

$$
=\left[\begin{array}{c|c}
B[I+C K V B] & B C K \\
\hline K V B & K
\end{array}\right]\left[\frac{f}{g}\right],
$$

where $g$ is a column vector of exogenous income. ${ }^{9}$ The preceding separated solutions (3.5) and (3.8) are equivalent to (3.10) in which we ignore $g$.

\section{Pattern of the Interrelational Income Multiplier between Regions}

An empirical application of our model is made for a three-region model of the Japanese economy by utilizing the large 1960 interregional input-output table published in 1966 by MITI (the Ministry of International Trade and Industry) that required took more than three years of preparation before publication. For analytical purposes, the original data tabulated in 9 blocks and 25 industry sectors was aggregated into three regions and 25 sectors, and the all estimations of parameters and calculations for our model were done by the MITI-staff together with the other calculations for general or conventional studies. ${ }^{10}$

The logic of separating the Japanese economy into three regions, namely, the Northeast, Middle and West, is based mainly on our desire to study the interrelationships between the advanced and backward areas in Japan; ${ }^{11}$ of these three regions, the Northeast and West are

9 The proof of $(3.10)$ is easily testifiable by the following identity:

$$
\left[\begin{array}{c|c}
B[I+C K V B] & B C K \\
\hline K V B & K
\end{array}\right]\left[\begin{array}{c|c}
I-A & -C \\
\hline-V & O
\end{array}\right]=\left[\begin{array}{l|l}
I & O \\
\hline O & I
\end{array}\right] .
$$

The expression (3.10) in this paper is equivalent to the formula (6) in K. Miyazawa, "Internal and External Matrix Multipliers in the Input-Output Model", Hitotsubashi Journal of Economics, vol. 7, no. 1 , June 1966 , p. 40 , in which, if we put $B_{1}=V B, B_{2}=B C$ and $M=K$, we get (3.10).

10 See, Ministry of International Trade and Industry, Shōwa 35 nen Chiikikan Sangyō-renkan-hyō ni yoru Nihon Keizai no Chiiki Renkan Bunseki (Interregional Analysis of Japanese Economy by the 1960 Interregional Input-Output Tables), Tokyo, 1967. The details on data-arrangements for application of our model are shown in Chap. 2 of the Supplement of this report.

11 The Northeast is defined to include Hokkaidō and Tōhoku, the Middle includes Kantō, Chūbu and Kinki, and the West consists of Chügoku, Shikoku and Kyūshū. The way dividing Japan into these blocks is based on the unit of each of the Regional Bureaus of MITI for the convenience of collecting regional data. Therefore, aggregation into three regions, consist with the economic and natural areas, is somewhat restricted by this base. 
relatively backward, and the Middle is the advanced area in Japan. The major industries are mainly concentrated in the Middle except for specialized regional sectors which exist because of the resource endowments and other reasons.

Table 1 is the interrelational income multiplier for the three-region model. The equations used here have been given in (2.2) and (2.3), i.e., $K=[I-L]^{-1}=[I-V B C]^{-1}$, where the orders of matrices $V, B$ and $C$ in this case are $3 \times 75,75 \times 75$ and $75 \times 3$ respectively. We take only the consumption of household sector as the endogenous variable, then, correspondingly, the elements of $V$ are not equal to value-added ratios for the whole economy, but to that of household sectors in which the fraction corresponding to the retained incomes of business sectors is excluded. The estimated papameters for the coefficient matrices $V$ and $C$ are given in the tables in the Appendix in a summarized form. ${ }^{12}$

TABle 1. INTERRELATIONAL INCOME MUltiplier FOR THE THREE-REGION MODEL

$$
K=[I-V B C]^{-1}
$$

\begin{tabular}{c|c|c|c|c}
\hline $\begin{array}{c}\text { region of } \\
\text { income origin }\end{array}$ & Northeast & Middle & West & Total \\
\hline $\begin{array}{c}\text { region of } \\
\text { income receipt }\end{array}$ & 1.55 & 0.07 & 0.04 & 1.66 \\
Northeast & 0.32 & 1.57 & 0.29 & 2.18 \\
Middle & 0.06 & 0.07 & 1.60 & 1.73 \\
West & 1.93 & 1.71 & 1.93 & 5.57 \\
\hline Total &
\end{tabular}

The interpretation of the entries in the interrelational income multiplier in the Table 1 follow from the nature of the equation (2.3). The $(r, s)$ th entry represents the total household income of the $r$ th region induced by expenditure from 1 unit of income earned in the sth region. For example, the figures in the first column of the Table tell us that: 1 unit of income earned in the Northeast gives rise directly and indirectly to 1.55 units' incomes in the Northeast itself, 0.32 units in the Middle, 0.06 units in the West, and in total 1.93 units in national economy as a whole through the medium of the expenditure and production activities.

Let us now compare the figures of the column totals in the last line of the Table. These values show the induced effects of each region's income on the household incomes of the national economy as a whole. Among these column sum values, the figure of the Middle, 1.71, takes a slightly lower value than those of the Northeast and West (both equal to 1.93). This is mainly because (1) the power of dispersion of industries shown in the Leontief inverse

12 We divide the consumption demand of household sector into endogenous and exogenous items, and only the former is included in the multiplier side. The exogenous household consumption included in the multiplicand side consists of the expenditure from the transfer income from government, and its propensity to consume is assumed equal to one.

With regard to the household income, we take the compensation of employees, wage income of unincorporated enterprises and income from properties as endogenous terms, while the retirement allow. ance in the private sectors and transfer income from government are treated as exogenous elements. The items of income corresponding to endogenous consumption expenditure are represented by all of the above terms, except for the last. The estimations of income and its allocation among regions and sectors are mainly based on the income statistics and input-output data. 
$B$ is relatively low in the Middle as compared with the Northeast and West, (2) as shown in the values of elements of matrix $V$ indicated in the Table $a$ in the Appendix, the weight of manufacturing sectors which have low value-added ratios is relatively large in the Middle area, (3) the weight of the primary sectors which have high value-added ratios is relatively large in the Northeast and West. However, roughly speaking, these values of column totals of three regions make little difference.

Against these column sum values showing the induced effects originating by each region, the values of row totals on the right hand in the Table show the induced effects received in each region due to expenditure from 1 unit of income in the regions of origin. In contrast to the column sum values, there are large differences in the row sum values. The Middle area receives highly induced effects amounting to 2.18 as the result of interregional income formation, but the Northeast and West receive the effects only amounting to 1.66 and 1.73 respectively. The contrast afforded by the row sum and column sum values in the interrelational income multiplier shows a characteristic feature of the Japanese interregional economy, namely, the concentration phenomenon of income formation in the advanced area.

To see this point more clearly, let us look at each element in the matrix $K$. As shown in the column elements of the Middle area, the induced effects of the Middle on each region appear intensively in the Middle itself, which takes a value of 1.57 , but only negligibly in the Northeast and West, those values being merely equal to 0.07 . By contrast, the induced effects of Northeast and West on the Middle take relatively high values which come up to 0.32 and 0.29 . That is to say, the effects considerably flow out from the backward to the advanced area.

The main reasons for results are that: (1) the sensitivity of dispersion for industries shown in the Leontief inverse $B$ is relatively high in the Middle, (2) as shown in the values of elements of matrix $C$ indicated by the Table $b$ in the Appendix, the relation between the consumption coefficients to the commodities for the Northeastern and Western regions produced in the Middle are relatively very much higher than that for the Middle's consumption coefficients to the Northeastern and Western commodities, (3) as shown in the values of elements of matrix $V$ indicated in Table $a$ in Appendix, the ratios of income-flow-out into the Middle from the Northeast and West are relatively higher than those of the opposite directions. The interaction between these coefficients in the process of propagation shows the concentration mechanism into the advanced area in income terms.

\section{Composition of Final Demand and the Multi-sector Income Multiplier}

The analyses in the preceding section have been based on the induced effects per unit of income, and do not connect the structure or commodity composition of autonomous demand in each region. In order to examine closely the latter side, we have to shift our attentions to the equation (2.5) which gives some insight into these problems.

Here we shall inquire into these problems in two different ways. In the fundamental equation of income formation $Y=K V B f$, (i) let us replace the autonomous demand vector $f$ by the matrix $F_{1}$ which shows autonomous expenditures separated into three regional demands, and (ii) replace the vector $f$ by the matrix $F_{2}$ showing autonomous expenditures separated 
into demand categories such as investment, government expenditure and export, etc. Then we get two types of direct and indirect income-formation such that:

$$
\begin{aligned}
& Y_{1}=K V B F_{1} \\
& Y_{2}=K V B F_{2}
\end{aligned}
$$

where, because the autonomous demand matrices $F_{1}$ and $F_{2}$ have the orders of $n k \times k$ and $n k \times m$ respectively ( $m$ is the number of demand categories), the income $Y_{1}$ and $Y_{2}$ become matrices having the orders of $k \times k$ and $k \times m$ respectively. The estimated results are shown in the Table 2 and 3.

The figures in Table $2 \cdot(\mathrm{a})$ are derived by dividing the column elements of $Y_{1}$, which are shown in Column (c), by the corresponding regional total demands, and they tell us the coefficients of inducement to income per unit of autonomous demand by each region. The

TABle 2. Direct and IndiRect Income Formation by Regional Demand*

(a) The coefficients of income-inducement per 1 unit of each region's demand**

\begin{tabular}{c|c|c|c|c}
\hline $\begin{array}{c}\text { region of } \\
\text { degion of } \\
\text { income receipt }\end{array}$ & Northeast & Middle & West & Average \\
\hline Northeast & 0.597 & 0.066 & 0.045 & 0.117 \\
Middle & 0.368 & 0.733 & 0.354 & 0.625 \\
West & 0.072 & 0.095 & 0.623 & 0.190 \\
\hline Total & 1.037 & 0.894 & 1.022 & 0.932 \\
\hline
\end{tabular}

(b) The percentage dependency of income-formation by type of regional demand*"

(unit: \%)

\begin{tabular}{c|c|c|c|c}
\hline $\begin{array}{c}\text { region of } \\
\text { region of } \\
\text { income receipt }\end{array}$ & Northeast & Middle & West & Total \\
\hline Northeast & 52.6 & 40.3 & 7.1 & 100.0 \\
Middle & 6.0 & 83.5 & 10.5 & 100.0 \\
West & 3.9 & 35.4 & 60.7 & 100.0 \\
\hline Average & 11.4 & 68.3 & 20.3 & 100.0 \\
\hline
\end{tabular}

(c) The direct and indirect income-formation due to regional demand

(unit: hundred million yen)

\begin{tabular}{c|r|r|r|r}
\hline $\begin{array}{c}\text { region of } \\
\text { demand origin }\end{array}$ & Northeast & Middle & West & Total \\
income receipt & 6,457 & 4,942 & 870 & 12,270 \\
\hline Northeast & 3,976 & 54,942 & 6,897 & 65,815 \\
Middle & 775 & 7,099 & 12,157 & 20,031 \\
West & 11,208 & 66,983 & 19,924 & 98,116 \\
\hline Total &
\end{tabular}

* Here, the regional demands are the totals of final demands other than endogenous consumption expenditure.

** Figures in (a) are derived by dividing the column elements of (c) by the corresponding regional demands, and figures in (b) are calculated by dividing the row elements of (c) by the corresponding totals shown in the fourth column. 
TABLE 3. DIRECT AND INDIRECT INCOME-FORMATION BY Autonomous Demand CATEgORY*

\begin{tabular}{c|c|c|c|c|c|c|c}
\hline & $\begin{array}{c}(1) \\
\text { Business } \\
\text { consumption } \\
\text { expenditure }\end{array}$ & $\begin{array}{c}\text { Exogenous** } \\
\text { household } \\
\text { consumption } \\
\text { expenditure }\end{array}$ & $\begin{array}{c}\text { General } \\
\text { government } \\
\text { consumption } \\
\text { expenditure }\end{array}$ & $\begin{array}{c}(4) \\
\text { Gross } \\
\text { domestic } \\
\text { fixed capital } \\
\text { formation }\end{array}$ & $\begin{array}{c}(5) \\
\text { Net } \\
\text { inventory } \\
\text { change }\end{array}$ & $\begin{array}{c}\text { Export } \\
\text { Expental }\end{array}$ & $\begin{array}{c}\text { Final } \\
\text { demand } \\
\text { total }\end{array}$ \\
\hline
\end{tabular}

(a) The coefficients of income-inducement per 1 unit of demand

\begin{tabular}{l|l|l|l|l|l|l|l|l}
\hline Northeast & 0.135 & 0.152 & 0.178 & 0.100 & 0.120 & 0.080 & 0.117 \\
Middle & 0.633 & 0.586 & 0.691 & 0.609 & 0.555 & 0.651 & 0.625 \\
West & 0.191 & 0.254 & 0.272 & 0.169 & 0.173 & 0.153 & 0.190 \\
\hline \multicolumn{1}{c|}{ Total } & 0.959 & 0.992 & 1.141 & 0.878 & 0.848 & 0.884 & 0.932 \\
\hline
\end{tabular}

(b) The percentage dependency of income-formation by type of demand

\begin{tabular}{l|l|l|l|l|l|l|l|l}
\hline Northeast & 9.7 & 8.7 & 23.9 & 39.9 & 6.6 & 11.2 & 100.0 \\
Middle & 8.5 & 6.2 & 17.3 & 45.3 & 5.7 & 17.0 & 100.0 \\
West & 8.4 & 8.9 & 22.4 & 41.2 & 5.9 & 13.2 & 100.0 \\
\hline \multicolumn{1}{c|}{ Total } & 8.7 & 7.1 & 19.2 & 43.6 & 5.9 & 15.5 & 100.0 \\
\hline
\end{tabular}

(c) Direct and indirect income-formation by type of demand

(unit: hundred million yen)

\begin{tabular}{|c|c|c|c|c|c|c|c|}
\hline Northeast & 1,193 & 1,071 & 2,931 & 4,889 & 814 & 1,372 & 12,270 \\
\hline Middle & 5,603 & 4,108 & 11,388 & 29,765 & 3,760 & 11,191 & 65,815 \\
\hline West & 1,692 & 1,783 & 4,488 & 8,259 & 1,174 & 2,635 & 20,031 \\
\hline Total & 8,488 & 6,962 & 18,807 & 42,913 & 5,748 & 15,198 & 98,116 \\
\hline \multicolumn{8}{|c|}{ Breakdown <Northeast $>$} \\
\hline Northeast & 536 & 662 & 2,215 & 2,216 & 452 & 377 & 6,457 \\
\hline Middle & 295 & 340 & 865 & 2,134 & 153 & 190 & 3,976 \\
\hline West & 58 & 67 & 152 & 428 & 33 & 36 & 775 \\
\hline Total & 889 & 1,069 & 3,231 & 4,778 & 638 & 602 & 11,208 \\
\hline \multicolumn{8}{|c|}{$<$ Middle $>$} \\
\hline Northeast & 579 & 319 & 550 & 229 & 319 & 889 & 4,942 \\
\hline Middle & 4,803 & 3,166 & 9,213 & 2,425 & 3,336 & 10,177 & 54,942 \\
\hline West & 605 & 352 & 668 & 375 & 428 & 1,299 & 7,099 \\
\hline Total & 5,987 & 3,837 & 10,432 & 3,028 & 4,083 & 12,365 & 66,983 \\
\hline \multicolumn{8}{|c|}{$<$ West $>$} \\
\hline Northeast & 78 & 90 & 166 & 386 & 43 & 107 & 870 \\
\hline Middle & 506 & 602 & 1,310 & 3,383 & 271 & 824 & 6,897 \\
\hline West & 1,028 & 1,363 & 3,667 & 4,085 & 713 & 1,300 & 12,157 \\
\hline Total & 1,612 & 2,056 & 5,144 & 7,855 & 1,027 & 2,230 & 19,924 \\
\hline
\end{tabular}

* The autonomous demand in this table excludes the consumption expenditure of endogenous terms, and includes exogenous terms.

** The exogenous household consumption consists of the expenditure from the transfer in come from government, and its propensity to consume is assumed to be equal to one. 
general features derived from Table 2-(a) are substantially the same as for the previous Table 1 , but between them there are some differences in detail. As before, the induced effects $b y$ region of origin (column totals in the last line of the Table) make clear the contrast between the induced effects by region of receipt (averages in the last column of the Table) and the latter values which show the concentration phenomenon of income-formation into the Middle, too. However, comparing with the preceding Table, the degree of concentration or the differential of values of Middle to those of Northeast and West are magnified markedly in this case (0.625 versus 0.117 and 0.190$)$. Clearly this result is produced by the pattern of autonomous demand in each region, and reflects the fact that the location of autonomous demand has a substantial effect in determining the regional income generation, especially in the income-receiving base.

Table 2-(b) translates this result into the percentage dependency of income formation by type of regional demand. For the national averages indicated in the last line of the Table, 68.3 percent of all the income comes directly and indirectly from the the initial expenditure in the Middle, and the contribution of expenditures in the Northeast and West are only 11.4 and 20.3 percent respectively. Further, as shown in each of the row elements, their regional pattern exhibits a striking contrast between the advanced and backward areas. In the Middle area, a large proportion of its income-generation depends on the demand originating in the Middle itself $(83.5 \%)$; the dependence on the Northeast and West are only 6.0 and 10.5 percent respectively. The converse is true in the backward areas: in the Northeast and West the self-dependent ratio of income formation is only $50 \sim 60$ percent, and a relatively large proportion of their incomes depends on expenditure originating in the Middle as the advanced area of Japan, that is, the dependency ratios on the Middle are 40.3 percent in the case of Northeast and 35.4 percent in the case of West.

Table 3 is concerned with the direct and indirect income generation by final demand category. Of course, the effects of endogenous consumption are included in the multiplier side, and in the multiplicand side; have we take business consumption, exogenous household consumption and government consumption as the exogenous items. The other exogenous elements are the investment expenditure, i.e. gross domestic fixed capital formation and net inventory change, and export demand. The total of the exogenous demand is the same as in the analyses of Table 2. As shown by the figures in Table 3-(a), the coefficients for the Middle area have excessively high values for all final demand items.

Looking at the last line of the Table 3-(a) and comparing Columns (1), (2) and (3) with Columns (4), (5) and (6), the multiplier effects on the household incomes for the national economy are somewhat higher in the case of exogenous consumption items than the case of investment items. That the value of the consumption multiplier is higher than that of the investment multiplier shows a characteristic not verifiable by the Keynesian type of macromultiplier model. ${ }^{13}$ However, as shown in the Table 3-(b), among the figures of percentage dependency by demand category, the weight of the effects of investment demand is excessively high reflecting the proportions in exogenous final demand expenditures.

In order to see the degree of leakage from the backward areas to the advance area by

1s Except in the case of general government consumption, the multiplier effects of each autonomous demand on incomes have values of less than one which may seem strange. But this is solely because the income formation treated in our empirical model is concerned with the household sector only and not with all value-added sectors in the whole economy. 
the type of demand category, we shall give a breakdown the induced pattern into three regions which is presented in Breakdown list in Table 3-(c). Looking at the columns for the Northeast and West and comparing the relative ratios of leakage to the Middle due to each demand item, the investment expenditure (especially the fixed capital formation) has extremely higher leakage ratios than those of the other autonomous demand items. The self-sufficient ratios of commodities needed directly and indirectly by investment are approximately only 50 percent in the case of the Northeast and West. By contrast, the corresponding ratio of selfsufficiency of the Middle amounts to more than 80 percent. This result suggests that a development program in the backward areas gives rise many leakages in the propagation process and generates much benefit to advanced area in terms of income.

It is instructive to examine how the industrial activity by sectors play a part in the interregional income-formation process. For the purpose of it, we must turn our attentions on the matrix multiplier $K V B$ itself, which is shown in Table 4 having the order of 3 rows and $75(=25 \times 3)$ columns.

Inquiring into the first $3 \times 25$ part tabulated as the Northeast Column (I), we can see what Northeastern industries have higher leakage-ratios to the Middle area. They are Electric machinery, Transportation equipment, Leather and rubber products, and Textile products with high values that exceed 0.35. But instead of the order of absolute values, if we take the relative ratios of leakage to self-induced effects, Electric machinery stands out clearly from other sectors with Precision machinery and Transportation equipment ranking next.

In the case of the West shown as the third $3 \times 25$ part (III) in the Table, the ranking of sectors shows a somewhat different pattern compared with that of the Northeast; the highest leakage-ratio to the Middle is found in the Textile industry, and next in Transportation equipment. But for the relative leakage ratio, Electric machinery has by far the highest value. On the whole, the sectors having relatively low ratios of self-induced effects are concentrated in some main manufacturing industries, and this appears to be even more the case for North east than for the West.

\section{Output Determination and Interregional Income Generation}

The analyses that have been made so far were limited to the income formation process, and the output determination side has appeared only in an indirect manner through the operation of the income multiplier as a matrix. We shall now directly study the output determination side, and compare briefly the analytical results based on two different models; namely, the model exo that regards the consumption demand as exogenous variable and the model endo that regards it as endogenous. These analyitical systems have been given in equations (3.1) to $(3.5) .^{14}$

${ }^{14}$ The first applications of interregional input-output analysis that took into account the endogenous income sector were given by H.B. Chenery's Italian two-region model and L.N. Moses' American threeregion model. See, H.B. Chenery, "Regional Analysis", in The Structure and Growth of the Italian Economy, by H.B. Chenery, P.G. Clark and V. Cao-Pinna, 1953; L.N. Moses, "The Stability of Interregional Trading Patterns and Input-Output Analysis", American Economic Revierv, Dec. 1955. However, in neither model, was the role of income formation taken out from the output-determination mechanism in a separated and exposed form. 
TABle 4. MATRIX MUltiplieR

\begin{tabular}{|c|c|c|c|c|c|c|}
\hline & $\begin{array}{c}1 \\
\text { Agriculture, } \\
\text { Forestry and } \\
\text { Fisheries }\end{array}$ & $\begin{array}{l}\quad 2 \\
\text { Coal and } \\
\text { Lignite } \\
\text { Mining }\end{array}$ & $\begin{array}{l}\quad 3 \\
\text { Mining } \\
\text { (except Coal } \\
\text { and Lignite } \\
\text { Mining) }\end{array}$ & $\begin{array}{l}4 \\
\text { Food and } \\
\text { Kindred } \\
\text { Products }\end{array}$ & $\begin{array}{c}5 \\
\text { Textile } \\
\text { Products } \\
\end{array}$ & $\begin{array}{c}6 \\
\text { Lumber and } \\
\text { Wood } \\
\text { Products }\end{array}$ \\
\hline \multicolumn{7}{|c|}{ (I) Northeast } \\
\hline Northeast & .906538 & 1.009660 & .460262 & .630688 & .676045 & .843026 \\
\hline Middle & .243481 & .280463 & .152632 & .242529 & .365511 & .268192 \\
\hline West & .053783 & 054627 & .030566 & .056604 & .091897 & .054708 \\
\hline Total & 1. 203802 & 1. 344749 & .643460 & .929821 & 1. 133454 & 1.165926 \\
\hline \multicolumn{7}{|c|}{ (II) Middle } \\
\hline Northeast & .049332 & .027020 & .015286 & .104287 & .064992 & .081788 \\
\hline Middle & .821486 & .250411 & .255333 & .561904 & .840818 & .821792 \\
\hline West & .059352 & .018038 & .018153 & .084368 & .129003 & .111207 \\
\hline Total & .930169 & .295469 & .288772 & .750559 & 1.034813 & 1.014786 \\
\hline \multicolumn{7}{|c|}{ (III) West } \\
\hline Northeast & .039351 & .031125 & .008866 & .041476 & .048937 & .041067 \\
\hline Middle & .238634 & .214965 & .061311 & .228554 & .445761 & .268799 \\
\hline West & 1.004575 & .851031 & .236874 & .689470 & .652674 & .914037 \\
\hline \multirow[t]{3}{*}{ Total } & 1.282560 & 1.097121 & .307052 & .959501 & 1.147373 & 1. 223903 \\
\hline & 14 & 15 & 16 & 17 & 18 & 19 \\
\hline & $\begin{array}{l}\text { Metal } \\
\text { Products }\end{array}$ & $\begin{array}{l}\text { Machinery } \\
\text { (n.e.c.) }\end{array}$ & $\begin{array}{c}\text { Electric } \\
\text { Machinery }\end{array}$ & $\begin{array}{l}\text { Transpor- } \\
\text { tation } \\
\text { Equipment }\end{array}$ & $\begin{array}{l}\text { Precision } \\
\text { Machinery }\end{array}$ & $\begin{array}{l}\text { Miscellaneous } \\
\text { Manufacturing }\end{array}$ \\
\hline \multicolumn{7}{|c|}{ (I) Northeast } \\
\hline Northeast & .532407 & .415495 & .358776 & .478679 & .386458 & .665567 \\
\hline Middle & .293503 & .274414 & .402575 & .380353 & .313989 & .344897 \\
\hline West & .071810 & .056836 & .061001 & .079384 & .048321 & .083648 \\
\hline Total & .897720 & .746745 & .822352 & .938416 & .748768 & 1.094111 \\
\hline \multicolumn{7}{|c|}{ (II) Middle } \\
\hline Northeast & .057636 & 052769 & .057546 & .054532 & .054100 & .087508 \\
\hline Middle & .691832 & .584263 & .630782 & .683974 & .700228 & .736311 \\
\hline West & .089505 & .075990 & .076658 & .089084 & .068522 & .102293 \\
\hline Total & .838973 & .713022 & .764986 & .827590 & .822850 & .926112 \\
\hline \multicolumn{7}{|c|}{ (III) West } \\
\hline Northeast & .040977 & .039003 & .042746 & .045068 & .031320 & .051917 \\
\hline Middle & .261317 & .292234 & .339961 & .356402 & .273683 & .299476 \\
\hline West & .571499 & .411371 & .399158 & .508611 & .447222 & .767488 \\
\hline Total & .873793 & .742608 & .781866 & .910081 & .752226 & 1. 118881 \\
\hline
\end{tabular}


OF INCOME-FORMATION ( $K V B$ )

\begin{tabular}{|c|c|c|c|c|c|c|}
\hline $\begin{array}{c}7 \\
\text { Pulp, Paper } \\
\text { and Paper } \\
\text { Products }\end{array}$ & $\begin{array}{c}8 \\
\text { Leather, } \\
\text { Leather Pro- } \\
\text { ducts and } \\
\text { Rubber } \\
\text { Products }\end{array}$ & Chemicals & $\begin{array}{c}10 \\
\text { Petroleum } \\
\text { and Coal } \\
\text { Products }\end{array}$ & $\begin{array}{l}11 \\
\text { Ceramic, } \\
\text { Clay and } \\
\text { Stone } \\
\text { Products }\end{array}$ & $\begin{array}{c}12 \\
\text { Primary } \\
\text { Iron and } \\
\text { Steel } \\
\text { Manufacturing }\end{array}$ & $\begin{array}{c}13 \\
\text { Primary } \\
\text { Nonferrous } \\
\text { Metal } \\
\text { Manufacturing }\end{array}$ \\
\hline
\end{tabular}

\begin{tabular}{|c|c|c|c|c|c|c|}
\hline $\begin{array}{l}.710320 \\
.267046 \\
.057485\end{array}$ & $\begin{array}{l}.704887 \\
.373968 \\
.069501\end{array}$ & $\begin{array}{l}.542014 \\
.236430 \\
.057964\end{array}$ & $\begin{array}{l}.488399 \\
.166134 \\
.043218\end{array}$ & $\begin{array}{l}.655752 \\
.254598 \\
.056331\end{array}$ & $\begin{array}{l}.440545 \\
.191649 \\
.037914\end{array}$ & $\begin{array}{l}.427490 \\
.181517 \\
.036507\end{array}$ \\
\hline 1. 034851 & 1. 148356 & .836409 & .697752 & .966680 & .670109 & .645514 \\
\hline .112561 & .062787 & .060910 & .032224 & .062738 & .059661 & .059643 \\
\hline .718789 & .783310 & .551874 & .228896 & .688831 & .432818 & .361897 \\
\hline .136215 & .088539 & .096881 & .047551 & .089783 & .078980 & .063054 \\
\hline .967565 & .934636 & .709666 & .308671 & .841353 & .571459 & .484594 \\
\hline .050683 & .041074 & .045674 & .016850 & .038872 & .035173 & .060441 \\
\hline .266685 & .334509 & .227787 & .110659 & .220726 & .182297 & .144228 \\
\hline .678919 & .718384 & .544705 & .357799 & .664984 & .389012 & .320252 \\
\hline .996287 & 1.094566 & .818166 & .485308 & .924582 & .606481 & .524921 \\
\hline $\begin{array}{l}20 \\
\text { Construction }\end{array}$ & $\begin{array}{c}21 \\
\text { Electricity, } \\
\text { Gas, Water } \\
\text { and Sanitary } \\
\text { Services }\end{array}$ & $\begin{array}{c}22 \\
\text { Wholesale } \\
\text { and Retail } \\
\text { Trade }\end{array}$ & $\begin{array}{l}23 \\
\text { Finance, } \\
\text { Real Estate } \\
\text { and other } \\
\text { Services }\end{array}$ & $\begin{array}{c}24 \\
\text { Transpor- } \\
\text { tation and } \\
\text { Warehousing }\end{array}$ & $\begin{array}{c}25 \\
\text { Unallocated }\end{array}$ & \\
\hline
\end{tabular}

\begin{tabular}{|c|c|c|c|c|c|}
\hline $\begin{array}{l}.597559 \\
.342581 \\
.069564\end{array}$ & $\begin{array}{l}.577969 \\
.175603 \\
.034666\end{array}$ & $\begin{array}{l}.957569 \\
.250550 \\
.047880\end{array}$ & $\begin{array}{l}.885472 \\
.310845 \\
.053373\end{array}$ & $\begin{array}{l}.813532 \\
.260188 \\
.066172\end{array}$ & $\begin{array}{l}.415535 \\
.235111 \\
.049605\end{array}$ \\
\hline 1. 009704 & .788237 & 1. 255999 & 1. 249689 & 1. 139892 & .700251 \\
\hline $\begin{array}{r}.071192 \\
.726509 \\
.103628\end{array}$ & $\begin{array}{r}.096956 \\
.510829 \\
.083456\end{array}$ & $\begin{array}{r}.046641 \\
.918089 \\
.054238\end{array}$ & $\begin{array}{l}.055398 \\
.978103 \\
.065907\end{array}$ & $\begin{array}{l}.071111 \\
.822386 \\
.080381\end{array}$ & $\begin{array}{r}.052801 \\
.493789 \\
.081708\end{array}$ \\
\hline .901329 & .691241 & 1. 018969 & 1.099407 & .973878 & .628298 \\
\hline $\begin{array}{r}.042013 \\
.318394 \\
.627697\end{array}$ & $\begin{array}{r}.026387 \\
.170733 \\
.642278\end{array}$ & $\begin{array}{r}.035126 \\
.246350 \\
1.005906\end{array}$ & $\begin{array}{l}.038302 \\
.300031 \\
.942282\end{array}$ & $\begin{array}{r}.069889 \\
.254636 \\
.735568\end{array}$ & $\begin{array}{r}.036963 \\
.244505 \\
.440008\end{array}$ \\
\hline .988104 & .839398 & 1. 287382 & 1. 280615 & 1.060093 & .721476 \\
\hline
\end{tabular}


TABLE 5. COMPARISON OF DiRECT AND INDIRECT REQUiREMENTS

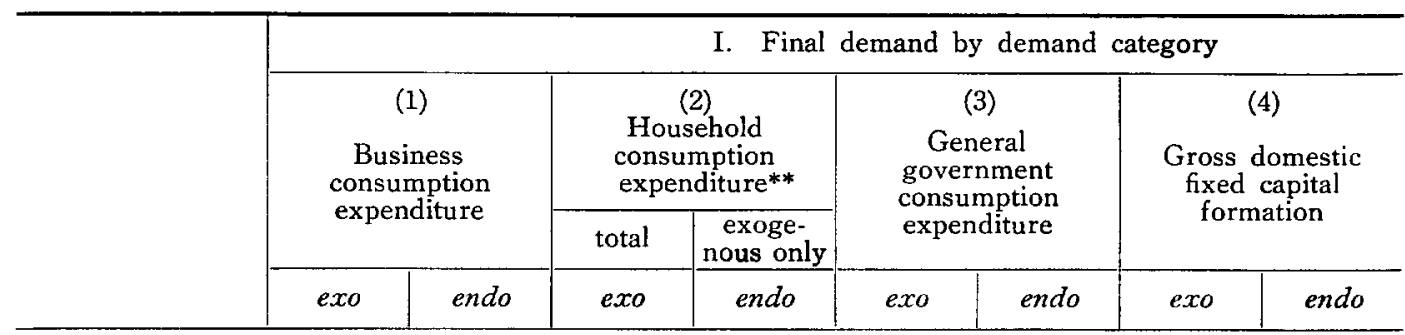

(a) The direct and indirect requirements of outputs

\begin{tabular}{l|r|r|r|r|r|r|r|r}
\hline Northeast & 1,936 & 3,737 & 20,982 & 3,181 & 3,640 & 7,871 & 10,456 & 18,487 \\
Middle & 11,914 & 20,420 & 106,860 & 14,448 & 17,844 & 35,910 & 91,527 & 135,559 \\
West & 2,986 & 5,665 & 34,521 & 5,624 & 6,123 & 12,817 & 23,427 & 36,699 \\
\hline \multicolumn{1}{|c|}{ Total } & 16,836 & 29,822 & 162,363 & 23,252 & 27,607 & 56,598 & 125,410 & 190,745 \\
\hline
\end{tabular}

(b) The percentage dependency of output requirements

\begin{tabular}{l|r|r|r|r|r|r|r|r}
\hline Northeast & 4.7 & 9.1 & 51.1 & 7.8 & 8.9 & 19.2 & 25.5 & 45.1 \\
Middle & 4.4 & 7.5 & 39.5 & 5.3 & 6.6 & 13.3 & 33.8 & 50.1 \\
West & 3.9 & 7.3 & 44.7 & 7.3 & 7.4 & 16.6 & 30.3 & 47.5 \\
\hline \multicolumn{1}{c}{ Total } & 4.3 & 7.7 & 41.7 & 6.0 & 7.1 & 14.5 & 32.2 & 49.0 \\
\hline
\end{tabular}

(c) The coefficients of output requirements per unit of demand

\begin{tabular}{l|r|r|r|r|r|r|r|r}
\hline Northeast & 0.219 & 0.422 & 0.248 & 0.453 & 0.221 & 0.477 & 0.214 & 0.378 \\
Middle & 1.346 & 2.307 & 1.263 & 2.061 & 1.082 & 2.178 & 1.871 & 2.772 \\
West & 0.337 & 0.640 & 0.408 & 0.802 & 0.371 & 0.777 & 0.479 & 0.750 \\
\hline \multicolumn{1}{c|}{ Total } & 1.902 & 3.369 & 1.919 & 3.316 & 1.674 & 3.432 & 2.564 & 3.900 \\
\hline
\end{tabular}

* The model exo regards the consumption demand as exogenous, and the model endo as endogenous; their solutions are given by $X=[I-A]^{-1}\left\{f_{c}+f\right\}$ and $X=[I-A]^{-1}[I-C V B]^{-1} f=$ $B[I+C K V B] f$ respectively.

** The consumption in Column-"total" in (2) includes the term $f_{\mathrm{c}}$, and that in Column"exogenous only" excludes $f_{c}$. 
of Output Between the Two Models*

\begin{tabular}{|c|c|c|c|c|c|c|c|c|c|c|c|}
\hline \multirow{2}{*}{\multicolumn{2}{|c|}{\begin{tabular}{|c|}
$(5)$ \\
$\begin{array}{c}\text { Net inventory } \\
\text { change }\end{array}$
\end{tabular}}} & \multirow{2}{*}{\multicolumn{2}{|c|}{$\begin{array}{c}(6) \\
\text { Export }\end{array}$}} & \multirow{2}{*}{\multicolumn{2}{|c|}{$\begin{array}{l}\text { Final demand } \\
\text { total }\end{array}$}} & \multicolumn{6}{|c|}{ II. Final demand by region } \\
\hline & & & & & & \multicolumn{2}{|c|}{$\begin{array}{c}\text { (i) } \\
\text { Northeast }\end{array}$} & \multicolumn{2}{|c|}{$\begin{array}{c}\text { (ii) } \\
\text { Middle }\end{array}$} & \multicolumn{2}{|c|}{$\begin{array}{c}\text { (iii) } \\
\text { West }\end{array}$} \\
\hline exo & endo & exo & endo & exo & endo & exo & endo & $e x o$ & endo & exo & endo \\
\hline \multicolumn{12}{|c|}{ (unit: hundred million yen) } \\
\hline 1,577 & 2,800 & 2,434 & 4,950 & 41,026 & 41,026 & 26,403 & 20,759 & 12,741 & 17,229 & 1,881 & 3,038 \\
\hline 10,921 & 16,655 & 31,741 & 47,815 & 270,807 & 270,807 & 14,847 & 16,987 & 232,375 & 224,823 & 23,585 & 28,997 \\
\hline 2,856 & 4,699 & 7,319 & 11,728 & 77,232 & 77,232 & 2,509 & 3,328 & 23,379 & 30,722 & 51,344 & 43,182 \\
\hline 15,354 & 24,154 & 41,495 & 64,493 & 389,065 & 389,065 & 43,760 & 41,074 & 268,495 & 272,775 & 76,810 & 75,217 \\
\hline \multicolumn{12}{|c|}{ (unit: \%) } \\
\hline 3.8 & 6.8 & 5.9 & 12.1 & 100.0 & 100.0 & 64.4 & 50.6 & 31.1 & 42.0 & 4.6 & 7.4 \\
\hline 4.0 & 6.2 & 11.7 & 17.7 & 100.0 & 100.0 & 5.5 & 6.3 & 85.8 & 83.0 & 8.7 & 10.7 \\
\hline 3.7 & 6.1 & 9.5 & 15.2 & 100.0 & 100.0 & 3.2 & 4. 3 & 30.3 & 39.8 & 66.5 & 55.9 \\
\hline 3.9 & 6.2 & 10.7 & 16.6 & 100.0 & 100.0 & 11.2 & 10.6 & 69.0 & 70.1 & 19.7 & 19.3 \\
\hline
\end{tabular}

\begin{tabular}{l|l|l|l|l|l|l|l|l|l|l|l}
\hline 0.233 & 0.413 & 0.142 & 0.288 & 0.224 & 0.391 & 1.230 & 1.920 & 0.102 & 0.230 & 0.051 & 0.156 \\
1.612 & 2.458 & 1.847 & 2.782 & 1.481 & 2.571 & 0.691 & 1.574 & 1.863 & 2.999 & 0.644 & 1.486 \\
0.421 & 0.694 & 0.426 & 0.683 & 0.422 & 0.734 & 0.117 & 0.308 & 0.187 & 0.410 & 1.404 & 2.214 \\
\hline 2.266 & 3.565 & 2.415 & 3.753 & 2.128 & 3.696 & 2.038 & 3.798 & 2.152 & 3.659 & 2.099 & 3.856 \\
\hline
\end{tabular}


Table 5 is a summarized version of this comparison. The figures in columns "exo" were computed by using the original Leontief inverse $B$, and the figures in columns "endo" were calculated by using the enlarged inverse $B[I-C V B]^{-1}$ or $B[I+C K V B]$. It should be noted that the final demand as a multiplicand differs in the two cases: in the case of the former it is $f_{c}+f$, and in the case of the latter it is $f$, where, of course, $f_{c}$ and $f$ are vectors of the endogenous consumption demand and the final demand other than endogenous consumption respectively.

With regard to the effects of final demand by the demand category indicated in Column $I$ in the Table, the direct and indirect requirements of output in the endogenous model have higher values than in the case of the exogenous model from the very nature of things (except the household consumption column (2)). But, by comparing these two cases it is interesting to see what types of the final demand have more influences through the endogenous changes in consumption demand. This can be found by dividing the figures of endo-columns by the corresponding figures of exo-columns. Further, if we breakdown the effects into industrial sectors, we may observe what sectors are relatively more effected by consumption demand and what sectors are not. It may be observed that there are differentials in the degree of this effect by sector and by region.

Next, let us compare the effects of regional demands in the two models, which are indicated in Column II in the Table. As shown in the diagonal blocks of Column II-(a), it is impressive that the effects on direct and indirect output requirements to the own region clearly decrease in the case of the endogenous model as compared with those of the exogenous model. The same is true for the percentage dependency of output requirements indicated by the diagonal blocks of Column II-(b). In other words, according to the transformation of the model into endogenous from exogenous, the inducement powers to the own region decrease and the powers to the other regions increase. A conclusion derived from this fact is as follows: if we study the problems by using the customary exogenous model, we may be liable to overvaluate the effects on the own region's output requirements.

With regard to the effects of regional demands on the national economy, their results are shown in the last line of Column II-(a) or -(b). For the endogenous model, in contrast to the exogenous model, the direct and indirect output requirements due to the demand originating in backward regions (Northeast and West) decrease their values, and those due to the demand originating in the advanced region (Middle) increase. Nevertheless, the powers of inducement itself invert this order of things. As shown in the last line of Column II-(c), in the case of the endogenous model, the coefficient of output requirements of the Middle takes the lowest ranking in order. Just the opposite was true in the case of the exogenous model in which the coefficient of the Middle has shown the highest value among the three regions. In short, according to the shift of the model to endogenous from exogenous, the output requirements due to the autonomous final demand originating in the advanced area increase in absolute value, but the degree of increase itself is not as large as that of the backward areas. These results are attributable to the working of the "subjoined inverse multiplier" $[I+C K V B]$ in the propagation process of output determination. 


\section{APPENDIX}

Table a. Coefficients of Value-Added of the Household SECTOR IN EACH REGION

(unit: $10^{-4}$ )

\begin{tabular}{|c|c|c|c|c|c|c|c|c|c|c|}
\hline & \begin{tabular}{|c|} 
Agri- \\
culture, \\
Forestry
\end{tabular} & Mining & \begin{tabular}{|c|} 
Light \\
industry
\end{tabular} & $\mid \begin{array}{c}\text { Heavy } \\
\text { industry }\end{array}$ & $\left|\begin{array}{c}\text { Con- } \\
\text { struction }\end{array}\right|$ & Trade $F_{S}$ & \begin{tabular}{|l|} 
Finance, \\
Services
\end{tabular} & $\begin{array}{c}\text { Trans- } \\
\text { porta- } \\
\text { tion }\end{array}$ & Others & Average \\
\hline \multicolumn{11}{|c|}{ Northeast } \\
\hline Northeast & 4,638 & 4,871 & 996 & 1,009 & 1,983 & 4,967 & 4,884 & 4,216 & 1,059 & 2,983 \\
\hline Middle & 8 & 181 & 44 & 50 & 69 & 36 & 36 & 81 & 9 & 43 \\
\hline West & 0 & 7 & 3 & 2 & 0 & 0 & 0 & 0 & 0 & 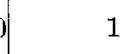 \\
\hline Total & $\overline{4,646}$ & 5,059 & 1,044 & 1,061 & 2,052 & 5,003 & 4,920 & 4,297 & 1,068 & 3,027 \\
\hline (Output) & 8,277 & 1,436 & 8,392 & 6,400 & 3,594 & 2,401 & 6,941 & 1,721 & 1,863 & 341,026 \\
\hline \multicolumn{11}{|c|}{ Middle } \\
\hline Northeast & & 12 & & 1 & 1 & 3 & 0 & & 0 & 0 \\
\hline Middle & 5,386 & 4,470 & 1,342 & 1,377 & 1,854 & 4,555 & 4,652 & 3,415 & 8,388 & 2,412 \\
\hline West & 1 & 2 & 1 & 1 & 1 & 3 & 2 & 2 & & 0 \\
\hline Total & 5,388 & 4,484 & 1,344 & 1,379 & 1,856 & 4,561 & 4,654 & 3,418 & 8,388 & 2,414 \\
\hline (Output) & 14,503 & 917 & 62,163 & 88,105 & 22,314 & 18,938 & 440,694 & 11,593 & 11,580 & 0270,807 \\
\hline \multicolumn{11}{|c|}{ West } \\
\hline Northeast & 0 & 1 & 0 & 1 & 1 & 1 & 2 & 2 & 0 & 0 \\
\hline Middle & 21 & 108 & 23 & 25 & 47 & 86 & 86 & 95 & 4 & 42 \\
\hline West & 5,296 & 4,440 & 1,140 & 994 & 1,919 & 5,076 & 4,934 & 3,520 & 1,057 & 2,588 \\
\hline Total & 5,317 & 4,549 & 1,163 & 1,020 & 1,967 & 5,163 & 5,022 & 3,617 & 1,062 & 2,631 \\
\hline (Output) & 9,513 & 1,582 & 15,075 & 23,360 & 5,906 & 3,553 & $3 \quad 11,986$ & 2,824 & 3,432 & 2) 77,232 \\
\hline \multicolumn{11}{|c|}{ National average } \\
\hline Northeast & 1,189 & 1,781 & 98 & 55 & 225 & 482 & 569 & 450 & 1,169 & 315 \\
\hline Middle & 2,427 & 1,151 & 983 & 1,036 & 1,317 & 3,481 & 3,196 & 2,479 & 5,776 & 1,692 \\
\hline West & 1,561 & 1,788 & 202 & 198 & 357 & 726 & 993 & 618 & 2,151 & 515 \\
\hline Total & 5,177 & 4,720 & 1,283 & 1,289 & 1,899 & 4,689 & 4,759 & 3,547 & 9,096 & 2,522 \\
\hline (Output) & 32,294 & 3,934 & 85,631 & 117,865 & 31,815 & 24,892 & 59,620 & 16,138 & $3 \quad 16,874$ & 4389,065 \\
\hline
\end{tabular}

* Sectors listed here are aggregated to 9 from the original 25 classifications for convenience.

** Unit of output: one hundred million yen. 
TABle b. CONSUMPtion Coefficients of EACH Region

(unit: $10^{-4}$ )

\begin{tabular}{|c|c|c|c|c|}
\hline & Northeast & Middle & West & $\begin{array}{l}\text { National } \\
\text { average }\end{array}$ \\
\hline $\begin{array}{l}\text { Northeast } \\
\text { Agriculture \& Forestry } \\
\text { Mining } \\
\text { Light Industry } \\
\text { Heavy Industry } \\
\text { Construction } \\
\text { Trade } \\
\text { Finance \& Services } \\
\text { Transportation } \\
\text { Others }\end{array}$ & $\begin{array}{r}764 \\
76 \\
2,830 \\
74 \\
0 \\
1,255 \\
2,151 \\
409 \\
140\end{array}$ & $\begin{array}{r}87 \\
1 \\
156 \\
5 \\
0 \\
5 \\
8 \\
1 \\
5\end{array}$ & $\begin{array}{r}42 \\
0 \\
43 \\
2 \\
0 \\
2 \\
1 \\
0 \\
0\end{array}$ & $\begin{array}{r}170 \\
11 \\
497 \\
13 \\
0 \\
175 \\
300 \\
57 \\
22\end{array}$ \\
\hline Sub-total & 7,699 & 268 & 90 & 1,245 \\
\hline $\begin{array}{l}\text { Middle } \\
\text { Agriculture \& Forestry } \\
\text { Mining } \\
\text { Light Industry } \\
\text { Heavy Industry } \\
\text { Construction } \\
\text { Trade } \\
\text { Finance \& Services } \\
\text { Transportation } \\
\text { Others }\end{array}$ & $\begin{array}{r}113 \\
0 \\
1,305 \\
499 \\
0 \\
157 \\
46 \\
11 \\
2\end{array}$ & $\begin{array}{r}429 \\
3 \\
3,789 \\
542 \\
0 \\
1,321 \\
2,496 \\
600 \\
259\end{array}$ & $\begin{array}{r}47 \\
0 \\
961 \\
423 \\
0 \\
165 \\
55 \\
4 \\
0\end{array}$ & $\begin{array}{r}302 \\
2 \\
2,828 \\
510 \\
0 \\
907 \\
1,623 \\
389 \\
168\end{array}$ \\
\hline Sub-total & 2,133 & 9,439 & 1,655 & 6,729 \\
\hline $\begin{array}{l}\text { West } \\
\text { Agriculture \& Forestry } \\
\text { Mining } \\
\text { Light Industry } \\
\text { Heavy Industry } \\
\text { Construction } \\
\text { Trade } \\
\text { Finance \& Services } \\
\text { Transportation } \\
\text { Others }\end{array}$ & $\begin{array}{r}24 \\
0 \\
133 \\
6 \\
0 \\
4 \\
1 \\
0 \\
0\end{array}$ & $\begin{array}{r}95 \\
2 \\
170 \\
12 \\
0 \\
4 \\
8 \\
2 \\
0\end{array}$ & $\begin{array}{r}612 \\
5 \\
3,388 \\
108 \\
0 \\
1,103 \\
2,398 \\
503 \\
137\end{array}$ & $\begin{array}{r}199 \\
3 \\
873 \\
32 \\
0 \\
245 \\
533 \\
111 \\
30\end{array}$ \\
\hline Sub-total & 168 & 293 & 8,255 & 2,026 \\
\hline $\begin{array}{l}\text { Total } \\
\text { Agriculture \& Forestry } \\
\text { Mining } \\
\text { Light Industry } \\
\text { Heavy Industry } \\
\text { Construction } \\
\text { Trade } \\
\text { Finance \& Services } \\
\text { Transportation } \\
\text { Others }\end{array}$ & $\begin{array}{r}901 \\
76 \\
4,268 \\
579 \\
0 \\
1,416 \\
2,198 \\
420 \\
142\end{array}$ & $\begin{array}{r}611 \\
6 \\
4,115 \\
559 \\
0 \\
1,330 \\
2,512 \\
603 \\
264\end{array}$ & $\begin{array}{r}702 \\
5 \\
4,392 \\
533 \\
0 \\
1,270 \\
2,454 \\
507 \\
137\end{array}$ & $\begin{array}{r}671 \\
16 \\
4,198 \\
555 \\
0 \\
1,328 \\
2,455 \\
557 \\
220\end{array}$ \\
\hline Total & $\begin{array}{l}10,000 \\
(0.870)\end{array}$ & $\begin{array}{l}10,000 \\
(0.761)\end{array}$ & $\begin{array}{c}10,000 \\
(0.855)\end{array}$ & $\begin{array}{l}10,000 \\
(0.794)\end{array}$ \\
\hline
\end{tabular}

* Figures in parenthesis in the last line show the total propensity to consume of each region.

** Sectors listed here are aggregated to 9 from the original 25 classifications for convenience. 